UDC 544.6

\author{
R. Namitha ${ }^{a}$, Devi Radhika ${ }^{a}$, G. Krishnamurthy ${ }^{b}$
}

\title{
HYDROTHERMALLY SYNTHESIZED CARBON NANOTUBES FOR ELECTROCHEMICAL HYDROGEN STORAGE APPLICATION
}

\author{
${ }^{a}$ Department of Chemistry, School of Engineering and Technology, Jain University, Bengaluru, \\ Karnataka, India \\ ${ }^{b}$ Department of Studies in Chemistry, Bangalore University, Bengaluru, Karnataka, India
}

\begin{abstract}
Worldwide commercial interest in carbon nanotubes (CNTs) is reflected in a production capacity that presently exceeds several thousand tons per year. Currently, CNTs are incorporated in various commercial products ranging from rechargeable batteries, automotive parts, and sporting goods. In this work, we studied electrochemical hydrogen storage of multi-walled carbon nanotubes (MWNTs) synthesized by hydrothermal procedure. The structure and morphology of as-synthesized carbon nanotubes were characterized by scanning electron microscopy and transmission electron microscopy. Furthermore, the electrochemical properties of MWNTs were elucidated by galvanostatic charge/discharge and cyclic voltammetric measurements. The electrochemical results demonstrated that MWNTs exhibited high electrochemical capacitance and stable cycling performance. Interestingly, MWNTs synthesized from hydrothermal procedure show high discharge capacity of $423 \mathrm{~mA} \mathrm{~h} \mathrm{~g}{ }^{-1}$ which corresponds to $\sim 1.5 \mathrm{wt} . \%$ hydrogen. This discharge capacity was reproducibly achieved at $25^{\circ} \mathrm{C}$ under normal atmosphere for about $100 \mathrm{mg}$ MWNT sample. The obtained results imply that the MWNTs synthesized by hydrothermal procedure are highly promising electrochemical hydrogen storage materials for rechargeable batteries.
\end{abstract}

Keywords: hydrothermal synthesis, carbon nanotubes, electrochemical hydrogen storage, charge and discharge processes, thermogravimetric analysis.

DOI: $10.32434 / 0321-4095-2019-124-3-30-34$

\section{Introduction}

The current stage of research into the nanotubular forms of materials is characterized by a great interest to their synthesis methods, improvement of these synthesis methods, study of the properties and attempts of industrial applications of these nanomaterials [1]. This existence form of carbon is intermediate between graphite and fullerenes. However, many of nanotube properties are drastically different from those of the above mentioned forms of carbon. Therefore nanotubes should be considered as a novel material with unique physicochemical properties showing good promise for many applications. The past couple of decades have witnessed the development on new mild soft solution based strategies for fabrication of low dimensional nanostructures such as nanorods, nanofibres, nanoplates, microspheres, nanotubes and their assemblies with controllable size, shape, phase, length scale and structured complexity [2]. Hydrothermal synthesis, as a traditional method but a good choice, has provided various general routes for the rational synthesis of a variety of low dimensional nanostructured materials. Hydrothermal method is a popular low temperature synthesis route without the addition of metal catalysts [3]. Many researchers call hydrothermal processing as a green processing or green chemistry. The homogeneity of hydrothermal process, cheapness, and availability of carbon precursor materials, without the need of catalyst, are advantageous favoring the scaling up of the new method.

There are many methods for hydrogen adsorption studies like volumetric and gravimetric method. Out of these methods, electrochemical method is one of the best methods for the study of hydrogen adsorption studies. There are many researchers attempt to study the hydrogen adsorption

(C) R. Namitha, Devi Radhika, G. Krishnamurthy, 2019

R. Namitha, Devi Radhika, G. Krishnamurthy 
of carbon nanotubes electrochemically. Electrochemical hydrogen storage was first studied by Nützenadel et al. [4]. They showed that nanotubecontaining material can electrochemically store an amount $110 \mathrm{~mA} \mathrm{~h} \mathrm{~g} \mathrm{~g}^{-1}$ of hydrogen. This capacity corresponds to hydrogen storage of $0.39 \mathrm{wt} . \%$. Lee et al. [5] studied hydrogen adsorption and storage in CNTs experimentally and theoretically and found that hydrogen exists as a form of $\mathrm{H}_{2}$ molecule in an empty space inside CNTs. Qin et al. [6] studied electrochemical hydrogen storage of MWNTs. They obtained a high discharge capacity of $200 \mathrm{~mA} \mathrm{~h} \mathrm{~g}{ }^{-1}$ and found that it had high rate capability and long charge-discharge cycle life. Rajalakshmi et al. [7] reported that electrodes made by compressing mixed purified and open SWNTs and copper powder into porous nickel collector show high electrochemical reversible charge capacity up to $800 \mathrm{~mA} \mathrm{~h} \mathrm{~g}{ }^{-1}$, corresponding to a hydrogen storage capacity of 2.9 wt.\%.

In this study, we report novel hydrothermal method for the synthesis of multiwalled carbon nanotubes using a common carbon source: ferrocene. In addition, we have performed electrochemical studies of hydrogen storage on the electrodes of these materials. The diameter and nanostructures were studied in detail using a suite of characterization methods, which included high-resolution scanning electron microscopy (SEM) and transmission electron microscopy (TEM). We measured the electrochemical charge-discharge hydrogen capacity of two different types of MWNTs with a difference of diameter range of under normal atmosphere.

\section{Materials and methodology}

In a typical synthesis, ferrocene and sulfur in 1:2 proportions were dissolved in a mixed solution of water and ethanol, and then $\mathrm{NaOH}$ pellets were added to the above solution under stirring for $30 \mathrm{~min}$ in a magnetic stirrer. The resulting homogeneous mixture was transferred to the reactor. The autoclave was heated to $200^{\circ} \mathrm{C}$, maintained at this temperature for $20 \mathrm{~h}$ and then naturally cooled to room temperature. The resulting black precipitate was filtered, washed with alcohol, acid and then distilled water several times and dried at $60^{\circ} \mathrm{C}$ in air. The synthesis part was published in detail elsewhere [8]. The synthesized product is subjected to electrochemical hydrogen storage study.

The morphology of the samples was inspected with a field emission scanning electron microscope JEOL JSM 6490 LV model and Phillips CM 12 Transmission electron microscope (TEM). The samples used for TEM analysis were prepared by sonication of dried products in absolute ethanol for
15 min and followed by putting 3-5 drops of the suspensions on carbon-coated copper grids. All the measurements were performed at room temperature. The electrochemical hydrogen adsorption measurements were carried out using an EG and G Potentiostat-Galvanostat mAutolab with PGSTAT30 instrument with GPES software.

\section{Results and discussion}

The morphologies of MWCNTs are compared via SEM and TEM measurement and the images are shown in Fig. 1, a and b, respectively. It can be seen that product is composed of a large quantity of MWCNTs and appear like bamboo sticks. We can see that a great deal of carbon nanotubes accumulate together and give bamboo sticks like appearance.

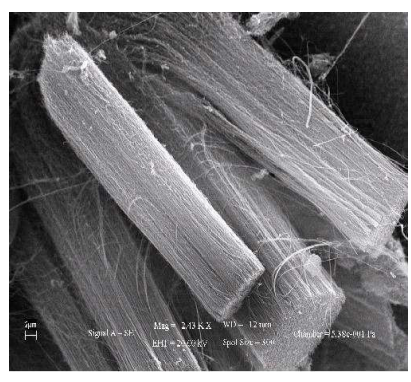

a

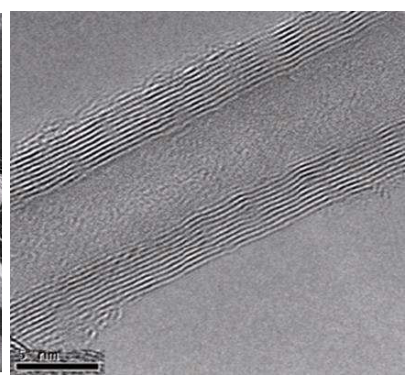

b
Fig. 1. SEM (a) and TEM (b) images of carbon nanotubes

The galvanostatic behavior of the CNTs synthesized through hydrothermal method was investigated. First, the electrode samples with 2:1 ratio of CNT and copper powder, respectively, were fully charged and discharged with a current density of $-100 \mathrm{~mA}$ and $+100 \mathrm{~mA}$ until the potential reached the cut-off value. Figure 2 shows the value of the electrode potential vs. the transferred amount of

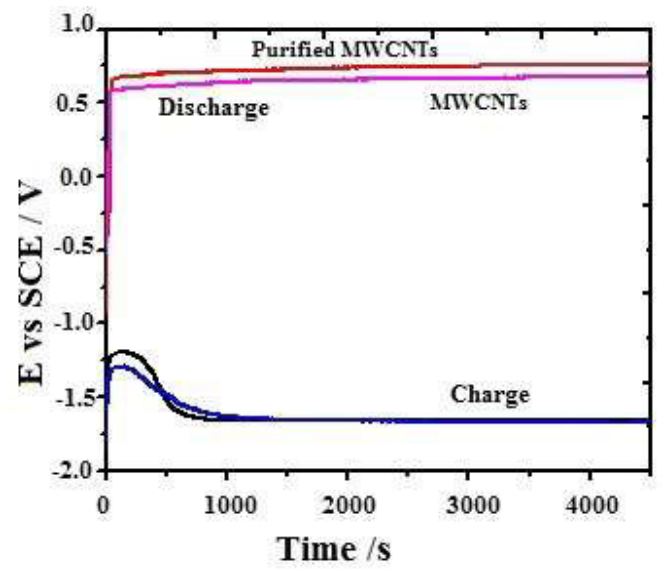

Fig. 2. The discharge curves for MWCNTs before and after acid treatment for the charge and discharge processes at a constant current of $100 \mathrm{~mA}$ 
charge for this experiment. Here, the potential responses during charging and discharging are depicted by curves before and after purification by acid treatment.

At a charge capacity of about $423 \mathrm{~mA} \mathrm{~h} \mathrm{~g}{ }^{-1}$, the potential stabilizes at a value close to $-1.7 \mathrm{~V}$. From the overall charging response, it can be deduced that about $423 \mathrm{~mA} \mathrm{~h} \mathrm{~g}^{-1}$ of charge could be stored in the material, the rest being irreversibly lost due to hydrogen gas evolution.

The discharge capacity was measured at different values of current supply from $10 \mathrm{~mA}$ to $100 \mathrm{~mA}$. The subsequent discharge shows a rather featureless potential response up until the cut-off potential and ca. $423 \mathrm{~mA} \mathrm{~h} \mathrm{~g}^{-1}$ of charge could be reversible extracted at $100 \mathrm{~mA}$ current which corresponds to $1.5 \mathrm{wt} . \%$ of hydrogen. All values of hydrogen adsorption of other electrodes made of both MWCNTs and copper are subtracted by the value hydrogen adsorption of copper electrode.

The hydrogen storage behavior of MWCNTs was studied in an electrolyte at the temperatures of $40,60,80$ and $100^{\circ} \mathrm{C}$. It was shown that the hydrogen storage capacity of MWCNTs depends on the electrolyte temperature according to the following order room temperature $>60>40>80>100$. It was observed that the maximum hydrogen adsorption of $423 \mathrm{~mA} \mathrm{~h} \mathrm{~g}^{-1}$ was achieved at $60^{\circ} \mathrm{C}$ which corresponds to $1.5 \mathrm{wt} . \%$ of hydrogen. Hence, it was also observed that there is a decrease in hydrogen adsorption capacity with an increase in temperature which conveys that the electrochemical hydrogen storage is a physisorption process.

To gain more detailed information on electrochemical responses measured using

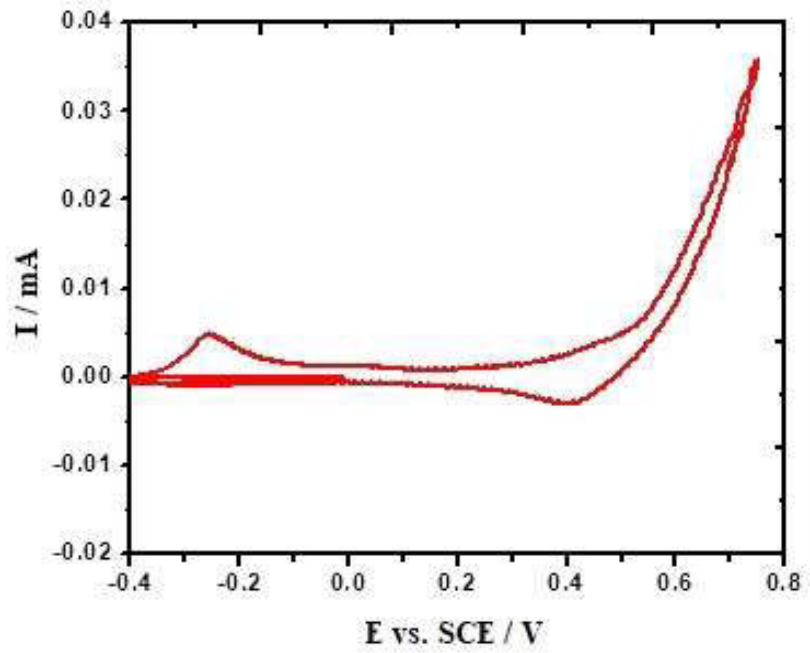

Fig. 3. Cyclic voltammogram of MWCNTs recorded with the scan rate of $100 \mathrm{mV} \mathrm{s}^{-1}$ galvanostatic methods, cyclic voltammetry technique (CV) was used. MWCNT electrode was charged and discharged using a scan rate of $100 \mathrm{mV} \mathrm{s}^{-1}$ and cycling between $-0.75 \mathrm{~V}$ to $+0.75 \mathrm{~V}$. The $\mathrm{CV}$ response for $15^{\text {th }}$ cycle is shown in Fig. 3 .

A stable cyclic voltammogram of MWCNT materials was obtained after the $2^{\text {nd }}$ cycle. The voltammogram indicates that the reaction is governed by diffusion process. The voltammogram suggests that the reduction peaks are due to the reduction of dissolved $\mathrm{O}_{2}$ to $\mathrm{HO}_{2}^{-}$and $\mathrm{OH}^{-}$, respectively. This indicates that charge is stored in the material via a charge transfer reaction.

Thermogravimetric studies have been employed to characterize the thermal decomposition, degradation, and stability properties of CNT. It was performed using a TG instrument from SETARAM Co. (SETSYS 2400). An alumina crucible was used as a sample container. The temperature was measured during TG using a $\mathrm{Pt}-\mathrm{Rh} 20 \%$ rode. Regarding the oxidation of metals at high temperatures, nitrogen was used instead of air. For the MWCNTs synthesized via solvothermal method, the results are illustrated in Fig. 4, they reveal that as-grown MWCNTs lose weight at the temperature of ca. $480^{\circ} \mathrm{C}$ in the $\mathrm{N}_{2}$ atmosphere. The lack of weight loss in the purified MWCNTs from 300 to $400^{\circ} \mathrm{C}$ indicates that no amorphous carbon existed in the MWCNTs. Analysis of the thermal stability of the CNTs is an appropriate method for determination of the overall quality of the obtained CNTs. TGA includes heating the produced CNT under nitrogen flow, where various components oxidize at different temperatures. The corresponding DSC curve for this CNTs sample shows that the process of thermal oxidation occurs

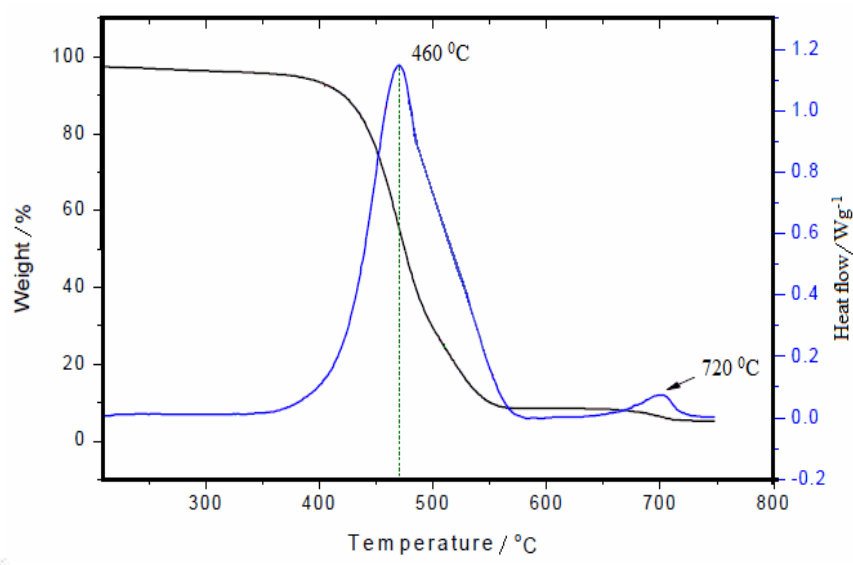

Fig. 4. Results of thermogravimetric analysis of a carbon nanotubes sample synthesized via solvothermal method in which the black line and blue line represents TGA and DSC curves, respectively 


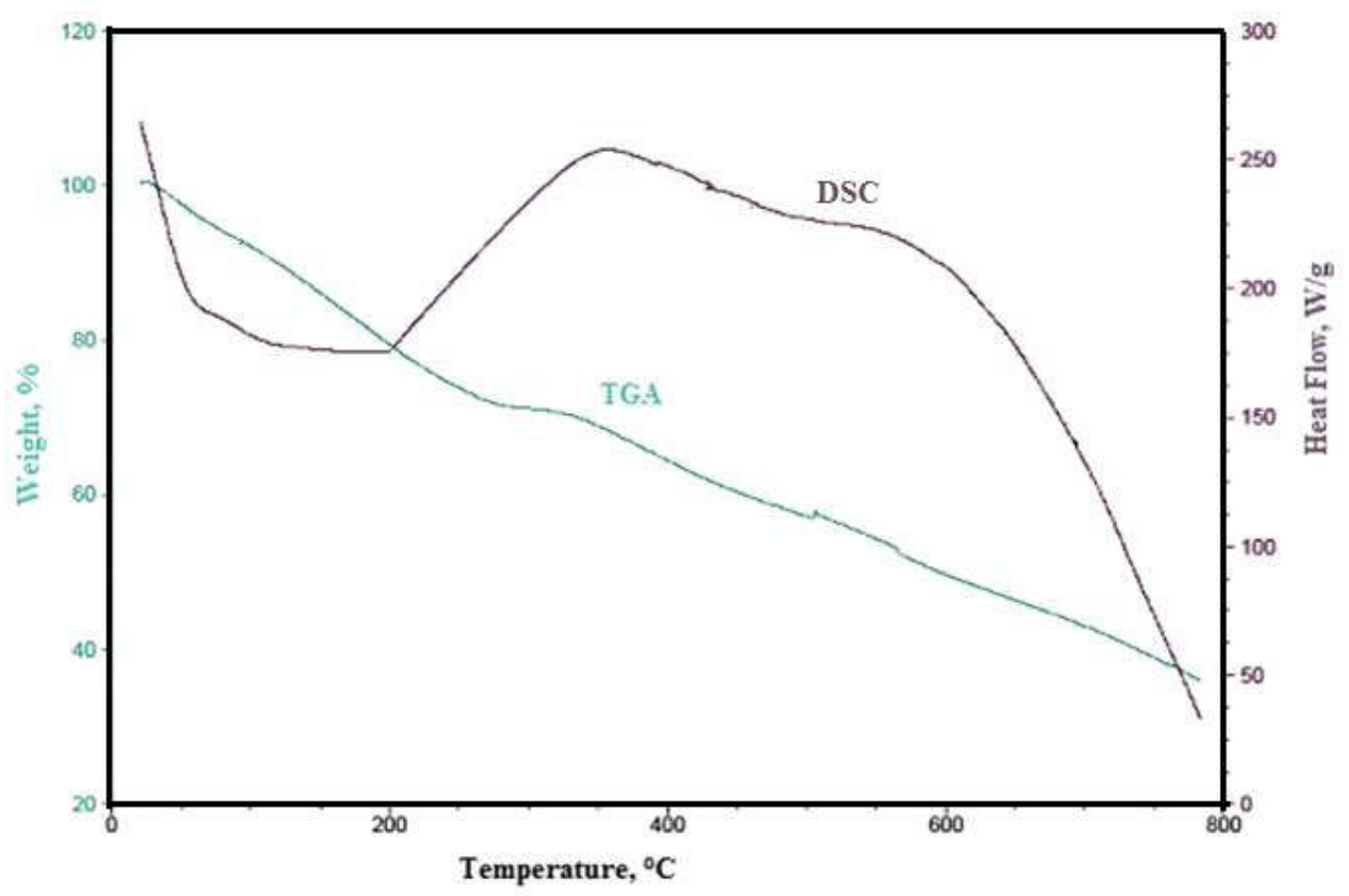

Fig. 5. Results of thermogravimetric analysis of a carbon nanotubes sample synthesized hydrothermally in which the green line and blue line represents TGA and DSC curves, respectively

also at two stages, the first one at $460^{\circ} \mathrm{C}$ and the second one at $720^{\circ} \mathrm{C}$. Also, lower thermal stability suggests that the produced CNTs samples have smaller diameters. A smaller diameter implies a high degree of curvature which means increased contact with the air and subsequently a higher reactivity towards nitrogen.

For the hydrothermally synthesized CNTs, the TGA results reveal that as-grown MWCNTs lose weight at the onset temperature of around $300^{\circ} \mathrm{C}$ and at $480^{\circ} \mathrm{C}$ in the $\mathrm{N}_{2}$ atmosphere (Fig. 5). We can see a continuous loss of weight due to impurities and amorphous carbon present in the sample. The corresponding DSC curve for produced carbon nanotubes sample shows that the process of thermal oxidation occurs also at two stages, the first one bellow $400^{\circ} \mathrm{C}$ and the second one at $600^{\circ} \mathrm{C}$.

\section{Conclusions}

In this work, we synthesized MWCNTs using ferrocene as a carbon source via hydrothermal synthesis route. The well aligned, straight carbon nanotubes bundles synthesized by hydrothermal routes are with diameter in the range of 50-60 nm and several micrometers in length. The electrochemical properties of MWCNTs were investigated. It was found that the charge-discharge capacity of MWCNTs is ca. $423 \mathrm{~mA} \mathrm{~h} \mathrm{~g}{ }^{-1}$ which corresponds to $\sim 1.5$ wt.\% of stored hydrogen. A relatively high hydrogen adsorption showed by hydrothermally synthesized MWNTs may be due to highly aligned structures of nanotubes.

\section{Acknowledgments}

The authors would like to acknowledge Central College Campus, Bangalore University for providing lab facility. The authors are thankful to DST-FIST [no. SR/FST/ETT-378/2014] for the instrumental facility at the Department premises. The authors also extend their acknowledgements to IISc, Bangalore for SEM facility. The authors also want to extend their thanks to IIT Bombay for TEM analysis.

\section{REFERENCES}

1. Popov V.N. Carbon nanotubes: properties and application // Mater. Sci. Eng. R. - 2004. - Vol.43. - P.61-102.

2. Choudhary N., Hwang S., Choi W. Carbon nanomaterials: a review // Handbook of Nanomaterials Properties. - Berlin, Heidelberg: Springer. - 2014. - P.709-769.

3. Yoshimura M., Byrappa K. Hydrothermal processing of materials: past, present and future // J. Mater. Sci. - 2008. Vol.43. - P.2085-2103.

4. Electrochemical storage of hydrogen in nanotube materials / C. Nützenadel, A. Zuttel, D. Chartouni, L. Schlapbach // Electrochem. Solid-State Lett. - 1999. - Vol.2. - P.30-32. 
5. A hydrogen storage mechanism in single-walled carbon nanotubes / Lee S.M., An K.H., Lee Y.H., Seifert G., Frauenheim T. // J. Am. Chem. Soc. - 2001. - Vol.123. - P.5059-5063.

6. Electrochemical hydrogen storage of multiwalled carbon nanotubes / Qin X., Gao X.P., Liu H., Yuan H.T., Yan D.Y., Gong W.L., Song D.Y. // Electrochem. Solid-State Lett. -2000. - Vol.3. - P.532-535.

7. Electrochemical investigation of single-walled carbon nanotubes for hydrogen storage / N. Rajalakshmi, K.S. Dhathathreyan, A. Govindaraj, B.C. Satishkumar // Electrochim. Acta. - 2000. - Vol.45. - P.4511-4515.

8. Krishnamurthy G., Namitha $R$. A novel method of synthesis of carbon nanotube by hydrothermal process // Int. J. Sci. Res. - 2013. - Vol.1. - No. 4. - P.358-362.

Received 16.04.2018

\section{ГІДРОТЕРМІЧНО СИНТЕЗОВАНІ ВУГЛЕЦЕВІ НАНОТРУБКИ ДЛЯ ВИКОРИСТАННЯ У ЕЛЕКТРОХІМІЧНОМУ АКУМУЛЮВАННІ ВОДНЮ}

\section{Р. Намітха, Деві Радхіка, Г. Крішнамуртхі}

Комериійний інтерес до вуглецевих нанотрубок (ВНТ) відображається у тому факті, що наразі відповідні виробничі потужності перевищили кілька тисяч тон щорічно. На даний момент ВНТ використовуються у різноманітних комериійних продуктах, що варіюються від акумуляторних батарей до автомобільних запчастин та спортивних товарів. В даній роботі ми дослідили електрохімічне акумулювання водню у багатошарових вуглецевих нанотрубках (БШВНТ), синтезованих гідротермальним шляхом. Структура та морфологія синтезованих вуглецевих нанотрубок охарактеризовані методом сканувальної електронної мікроскопії та трансмісійної електронної мікроскопії. Електрохімічні властивості БШВНТ були оцінені гальваностатичним зарядженням/розрядженням і ииклічною вольтамперометрією. Отримані результати показали, що БШВНТ проявляють високу електрохімічну ємність і стабільну поведінку при циклюванні. Цікаво, що синтезовані гідротермальним методом, мають високу розрядну ємність близько 423 мА год $2^{-1}$, що відповідає 1.5 мас.\% водню. Ця розрядна ємність була зафіксована при температурі $25^{\circ} \mathrm{C}$ і нормальному тиску для зразка БШВНТ масою приблизно 100 ме. Такий результат означає, що БШВНТ є вельми перспективним матеріалом для електрохімічного акумулювання водню у акумуляторних батареях.

Ключові слова: гідротермальний синтез, вуглецеві нанотрубки, електрохімічне акумулювання водню, процеси заряду та розряду, термогравіметричний аналіз.

\section{HYDROTHERMALLY SYNTHESIZED CARBON NANOTUBES FOR ELECTROCHEMICAL HYDROGEN STORAGE APPLICATION}

\author{
R. Namitha ${ }^{a,}$ ", Devi Radhika ${ }^{a}$, G. Krishnamurthy ${ }^{b}$ \\ a Department of Chemistry, School of Engineering and Technol- \\ ogy, Jain University, Bengaluru, Karnataka, India \\ ${ }^{\mathrm{b}}$ Department of Studies in Chemistry, Bangalore University, \\ Bengaluru, Karnataka, India \\ *e-mail: namitha19kkp@gmail.com
}

Worldwide commercial interest in carbon nanotubes (CNTS) is reflected in a production capacity that presently exceeds several thousand tons per year. Currently, CNTs are incorporated in various commercial products ranging from rechargeable batteries, automotive parts, and sporting goods. In this work, we studied electrochemical hydrogen storage of multi-walled carbon nanotubes (MWNTs) synthesized by hydrothermal procedure. The structure and morphology of as-synthesized carbon nanotubes were characterized by scanning electron microscopy and transmission electron microscopy. Furthermore, the electrochemical properties of MWNTs were elucidated by galvanostatic charge/discharge and cyclic voltammetric measurements. The electrochemical results demonstrated that MWNTs exhibited high electrochemical capacitance and stable cycling performance. Interestingly, MWNTs synthesized from hydrothermal procedure show high discharge capacity of $423 \mathrm{~mA} \mathrm{~h} \mathrm{~g}^{-1}$ which corresponds to $\sim 1.5 \mathrm{wt} . \%$ hydrogen. This discharge capacity was reproducibly achieved at $25^{\circ} \mathrm{C}$ under normal atmosphere for about $100 \mathrm{mg}$ MWNT sample. The obtained results imply that the MWNTs synthesized by hydrothermal procedure are highly promising electrochemical hydrogen storage materials for rechargeable batteries.

Keywords: hydrothermal synthesis; carbon nanotubes; electrochemical hydrogen storage; charge and discharge processes; thermogravimetric analysis.

\section{REFERENCES}

1. Popov V.N. Carbon nanotubes: properties and application. Materials Science and Engineering: R: Reports, 2004, vol. 43 , pp. 61-102.

2. Choudhary N., Hwang S., Choi W. Carbon nanomaterials: a review. In: Bhushan B., Luo D., Schricker S., Sigmund W., Zauscher S. (eds.). Handbook of Nanomaterials Properties. Springer, Berlin, Heidelberg, 2014, pp. 709-769.

3. Yoshimura M., Byrappa K. Hydrothermal processing of materials: past, present and future. Journal of Materials Science, 2008, vol. 43, pp. 2085-2103.

4. Nützenadel C., Zuttel A., Chartouni D., Schlapbach L. Electrochemical storage of hydrogen in nanotube materials. Electrochemical and Solid-State Letters, 1999, vol. 2, pp. 30-32.

5. Lee S.M., An K.H., Lee Y.H., Seifert G., Frauenheim T. A hydrogen storage mechanism in single-walled carbon nanotubes. Journal of the American Chemical Society, 2001, vol. 123, pp. 5059-5063.

6. Qin X., Gao X.P., Liu H., Yuan H.T., Yan D.Y., Gong W.L., Song D.Y. Electrochemical hydrogen storage of multiwalled carbon nanotubes. Electrochemical and Solid-State Letters, 2000, vol. 3, pp. 532-535.

7. Rajalakshmi N., Dhathathreyan K.S., Govindaraj A., Satishkumar B.C. Electrochemical investigation of single-walled carbon nanotubes for hydrogen storage. Electrochimica Acta, 2000, vol. 45 , pp. 4511-4515.

8. Krishnamurthy G., Namitha R. A novel method of synthesis of carbon nanotube by hydrothermal process. International Journal of Science Research, 2013, vol. 1, no. 4, pp. 358-362. 